\title{
16q24.3 microdeletion syndrome
}

INSERM

\section{Source}

INSERM. (1999). Orphanet: an online rare disease and orphan drug data base. $16 q 24.3$ microdeletion syndrome. ORPHA:261250

$16 q 24.3$ microdeletion syndrome is a recently described syndrome associated with variable developmental delay, facial dysmorphism, seizures and autistic spectrum disorder. 